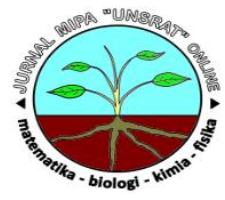

\title{
Uji Antibakteri Sediaan Masker Peel Off Ekstrak Etanol Daun Alpukat (Persea ameicana Mill.) terhadap Bakteri Staphylococcus epidermidis sebagai Antijerawat
}

\author{
Esterlina Aldora Puluha ${ }^{*}$,Hosea Jaya Edy ${ }^{*}$,Jainer Pasca Siampa* \\ Program Studi Farmasi, FMIPA, Universiitas Sam Ratulangi Manado, Indonesia
}

KATA KUNCI

Alpukat (Persea americana Mill.)

Antibakteri

Masker Peel Off

Staphylococcus epidermidis.

\begin{abstract}
A B S T R A K
Daun Alpukat memiliki kandungan antara lain saponin, alkaloid, flavonoid, polifenol, quersetin yang bersifat sebagai antibakteri. Penelitian ini bertujuan untuk mendapatkan konsentrasi terbaik dari ekstrak etanol daun alpukat (Persea americana Mill.) yang diformulasikan sebagai sediaan masker gel peel off berdasarkan uji aktivitas antibakteri terhadap bakteri Staphylococcus epidermidis. Penelitian ini menggunakan metode ekperimental laboratorium. Formula sediaan masker gel peel off ekstrak daun Alpukat dibuat dengan variasi konsentrasi 0.1\%; 0.15\%; 0.2\%; 0.25\% dan $0.3 \%$. Ekstrak tanaman daun alpukat diperoleh dengan cara maserasi menggunakan pelarut etanol 96\%. Pengujian antibakteri dengan metode sumuran diameter zona hambat yang paling besar yaitu pada konsentrasi $0,3 \%$ dengan diameter zona hambat $3 \mathrm{~mm} \pm 0,32$ dan kemampuan daya hambat dikategorikan lemah. Dapat disimpulkan bahwa konsentrasi terbaik dari ekstrak etanol daun Alpukat (Persea americana Mill.) yang diformulasikan sebagai sediaan masker gel peel off yaitu pada konsentrasi $0.3 \%$ dan dikategorikan kemampuan daya hambat lemah

A B S T R A C T

Avocado leaves contains saponins, alkaloids, flavonoids, polyphenols, quercetin which are as antibacterial properties. This study aims to obtain the best concentration of ethanol extract of avocado leaves (Persea americana Mill.) which is formulated as a gel peel off mask preparation based on antibacterial activity test against Staphylococcus epidermidis bacteria. This study uses a laboratory experimental method. Avocado leaf extract peel off mask gel formula is made with a concentration variation of $0.1 \%$; $0.15 \% ; 0.2 \%$; $0.25 \%$ and $0.3 \%$. Avocado leaf extract is obtained by maceration using $96 \%$ ethanol solvent. Antibacterial testing with the largest inhibition zone diameter wells method is at a concentration of $0.3 \%$ with a diameter of inhibition zone $3 \mathrm{~mm} \pm 0.32$ and the ability of inhibition is categorized as weak. It can be concluded that the best concentration of ethanol extract of avocado leaves (Persea americana Mill.) Which is formulated as a gel peel off mask preparation is at a concentration of $0.3 \%$ and categorized as weak inhibitory ability
\end{abstract}

KEYW OR D S

3D

SMK Indramayu

Aplication
TERSEDIA ONLINE

31 Oktober 2019

\section{Pendahuluan}

Penyakit kulit dapat menyerang siapa saja dan dapat menyerang pada bagian tubuh mana pun. Penyakit kulit dapat disebabkan oleh beberapa faktor seperti lingkungan dan kebiasaan sehari-hari yang buruk, perubahan iklim, virus, bakteri, alergi, daya tahan tubuh dan lain-lain (Pardiansyah, 2015). Penyakit kulit yang sering diderita adalah jerawat.

Jerawat biasanya muncul pada permukaan kulit wajah, leher, dada dan pungggung pada saat kelenjar minyak pada kulit terlalu aktif sehingga

*Corresponding author: Program Studi Farmasi, FMIPA, Universitas Sam Ratulangi, Manado;

Email address: esterlinaaldora@gmail.com

Published by FMIPA UNSRAT (2019) 
pori-pori kulit akan tersumbat oleh timbunan lemak yang berlebihan. Jika timbunan itu bercampur dengan keringat, debu dan kotoran lain, maka akan menyebabkan timbunan lemak dan bintik hitam di atasnya yang disebut komedo (Djajadisastra, dkk., 2009). Salah satu pengobatan jerawat yaitu dengan menggunakan bahan dari alam.

Indonesia adalah negara yang luas dengan iklim tropis dan lahan subur. Situasi ini menyebabkan banyak tanaman tumbuh subur, termasuk tanaman obat. Indonesia memiliki banyak tanaman obat dan mudah ditemukan di sekitar kita karena tanaman ini tumbuh subur. Masyarakat Indonesia telah lama menggunakan tanaman dalam pengobatan tradisional. Penggunaan tanaman obat semakin populer dan semakin meluas secara global dengan perkembangan ilmu pengetahuan (Edy, dkk., 2017). Salah satu tumbuhan yang terdapat di alam Indonesia yaitu Daun Alpukat (Persea americana Mill.).

Kandungan daun alpukat antara lain saponin, alkaloid, flavonoid, polifenol, quersetin yang bersifat antiradang dan antibakteri (Cushnie and Lamb, 2005). Penelitian terdahulu menyatakan bahwa kandungan flavonoid yang terdapat dalam daun alpukat (Persea americana Mill.) mempunyai aktivitas sebagai antifungi, antiviral dan antibakteri (Christianto, dkk., 2012). Berdasarkan penelitian sebelumnya hasil uji Konsentrasi Hambatan Minimal (KHM) ekstrak daun alpukat terhadap pertumbuhan bakteri Staphylococcus epidermidis pada konsentrasi $0,2 \%$ dengan rerata diameter zona hambat sebesar 0,50 mm (Yunikasari, 2016).

Kosmetik wajah dapat diperoleh dalam berbagai bentuk sediaan, salah satunya dalam bentuk masker wajah gel peel off (Vieira, dkk., 2009). Masker wajah merupakan kosmetik perawatan kecantikan yang sangat popular untuk meningkatkan kualitas kulit (Yeom, dkk., 2011).

\section{Material dan Metode \\ Alat dan Bahan}

Peralatan gelas, kertas saring, corong, oven, batang pengaduk, $\mathrm{pH}$ meter, timbangan analitik, inkubator $\left(\right.$ EcoCell $\left.{ }^{\circledR}\right)$, pemberat, plat kaca, penggaris, mikropipet, dan cawan petri, mixer, jangka sorong, LAF, autoclave, dan lemari pendingin, Simplisia Daun Alpukat, etanol 96\%, PVA, HPMC, TEA, Gliserin, Aquadest, Nutrien Agar (NA), bakteri Staphylococcus epidermidis ATCC 12228, larutan $\mathrm{BaCl}_{2} 1 \%, 1,175 \%$, larutan $\mathrm{H}_{2} \mathrm{SO}_{4} 1 \%$, larutan $\mathrm{NaCl} 0,9 \%$, dan gel spot “Acnes ${ }^{\circledR}$.

\section{Ekstraksi}

Pengambilan sampel daun Alpukat (Persea americana Mill.) di kecamatan Girian, kota Bitung. Sampel dipreparasi dan daun yang terkumpul dicuci bersih dengan air mengalir untuk menghilangkan pengotor. Pengeringan daun dilakukan di dalam oven dengan suhu $40^{\circ} \mathrm{C}$ sampai daun kering sempurna. Daun kering kemudian diserbuk lalu diayak menggunakan ayakan tepung dan dilanjutkan dengan proses perendaman (Edy, dkk., 2016).

Proses ekstraksi serbuk daun Alpukat menggunakan sistem metode maserasi. Serbuk daun Alpukat ditimbang sebanyak $400 \mathrm{~g}$ dan dimasukkan dalam toples lalu ditambahkan pelarut etanol 96\% sebanyak $2000 \mathrm{~mL}$ didiamkan selama 3 hari sambil sesekali diaduk. Setelah 3 hari disaring dengan menggunakan kertas saring dan menghasilkan filtrat 1 dan debris 1 . Debris 1 yang ada kemudian direndam lagi (remaserasi) dengan pelarut yang sama selama 2 hari sambil sesekali diaduk. Setelah 2 hari, sampel disaring sehingga menghasilkan filtrat 2 dan debris 2 . Filtrat 1 dan filtrat 2 dicampurkan menjadi satu lalu dievaporasi menggunakan rotary evaporator sehingga diperoleh ekstrak kental lalu kemudian dikerok dan di masukkan ke dalam pot salep dan di timbang.

\section{Formulasi}

Tabel 1. Formulasi sediaan masker peel off ekstrak etanol daun Alpukat (Persea americana Mill.)

\begin{tabular}{llllll}
\hline Bahan & \multicolumn{5}{c}{ Formula (\%b/v) } \\
\cline { 2 - 6 } & $F_{1}$ & $F_{2}$ & $F_{3}$ & $F_{4}$ & $F_{5}$ \\
& & & & & \\
Ekstrak & $0,1 \%$ & $0,15 \%$ & $0,2 \%$ & $0,25 \%$ & $0,3 \%$ \\
etanol & & & & & \\
$\begin{array}{l}\text { Daun } \\
\text { Alpukat }\end{array}$ & & & & & \\
PVA & 10 & 10 & 10 & 10 & 10 \\
HPMC & 1 & 1 & 1 & 1 & 1 \\
Gliserin & 12 & 12 & 12 & 12 & 12 \\
TEA & 0,15 & 0,15 & 0,15 & 0,15 & 0,15 \\
Aquade & 100 & 100 & 100 & 100 & 100 \\
stilata & & & & & \\
\hline
\end{tabular}

Terlebih dahulu dikembangkan HPMC dalam aquadest dingin dengan cara ditaburkan sedikit demi sedikit dan didiamkan \pm 24 jam hingga mengembang sempurna. PVA dikembangkan dalam aquadest menggunakan mixer. Kemudian, ditambahkan gliserin, yang telah dilarutkan dalam aquadestilata panas, HPMC, serta TEA secara berturut-turut ke dalam massa PVA, diaduk hingga homogen menggunakan mixer. Lalu disterilkan dalam autoklaf pada suhu $121^{\circ} \mathrm{C}$ dengan tekanan 1 atm selama 15 menit. Setelah itu ditambahkan ekstrak yang telah diencerkan dalam aquadest. Lalu diaduk hingga homogen dan dilakukan hal yang sama pada ekstrak yang lain.

\section{Pengujian Antibakteri Sterilisasi Alat}

Alat-alat yang akan digunakan dalam penelitian aktivitas antibakteri ini dicuci bersih menggunakan sabun, kemudian dikeringkan dan setelah kering dibungkus dengan aluminium foil. Setelah itu disterilkan terlebih dahulu dengan menggunakan autoklaf pada suhu $121{ }^{\circ} \mathrm{C}$ tekanan 1 atm selama 15 menit, pinset, jarum ose dipijarkan diatas api bunsen dan media disterilkan di autoklaf pada suhu 
$121{ }^{\circ} \mathrm{C}$ tekanan $1 \mathrm{~atm}$ selama 15 menit (Ortez, 2005).

\section{Pembuatan Media dasar}

Nutrien Agar (NA) sebanyak 2,52 g dilarutkan dalam $90 \mathrm{~mL}$ aquades $(28 \mathrm{~g} / 1000 \mathrm{~mL})$ menggunakan Erlenmeyer. Langkah berikutnya dihomogenkan dengan stirer di atas penangas air sampai mendidih. Kemudian media yang sudah homogen disterilkan dalam autoklaf dengan suhu $121^{\circ} \mathrm{C}$ tekanan $1 \mathrm{~atm}$ selama 15 menit, selanjutnya didinginkan sampai suhu $\pm 45^{\circ}-50^{\circ} \mathrm{C}$. Media dasar ini digunakan untuk pembuatan media pengujian sebagai lapisan dasar.

\section{Pembuatan Media Pembenihan}

Nutrien Agar (NA) sebanyak 2,52 g dilarutkan dalam $90 \mathrm{~mL}$ aquades menggunakan erlenmeyer. Kemudian dihomogenkan dengan stirrer diatas penangas air sampai mendidih. Selanjutnya media yang sudah homogen kemudian disterilkan dalam autoklaf pada suhu $121^{\circ} \mathrm{C}$ tekanan 1 atm selama 15 menit, langkah selanjutnya didinginkan pada suhu $\pm 45^{\circ} \mathrm{C}-50^{\circ} \mathrm{C}$. Media pembenihan ini digunakan untuk pembuatan media pengujian sebagai lapisan kedua.

\section{Pembuatan Suspensi Uji Bakteri}

Bakteri uji pada media agar miring diambil dengan menggunakan kawat ose steril lalu disuspensikan ke dalam tabung yang berisi $10 \mathrm{~mL}$ larutan $\mathrm{NaCl}$ 0,9 \% dalam tabung reaksi kemudian dikocok hingga diperoleh larutan yang keruh. Kekeruhan ini dipakai sebagai standar kekeruhan suspensi bakteri uji.

\section{Pembuatan Media Pengujian}

Media uji dibuat dengan metode difusi agar dengan cara sumuran dengan 2 lapisan media agar dengan pengerjaan sebagai berikut:

1. Lapisan dasar dibuat dengan cara menuangkan masing-masing $15 \mathrm{~mL}$ NA ke dalam 3 cawan petri, selanjutnya dibiarkan memadat.

2. Setelah memadat, pada permukaan lapisan dasar ditanam 7 pencadang yang diatur jaraknya agar daerah pengamatan tidak bertumpu.

3. Suspensi bakteri dicampurkan ke dalam pembenihan NA.

4. Kemudian dituangkan $15 \mathrm{~mL} \mathrm{NA}$ media pembenihan ke dalam masing-masing cawan petri.

5. Setelah lapisan kedua memadat, pecandang diangkat secara aseptik menggunakan pinset dari masing-masing cawan petri, sehingga terbentuk sumur-sumur yang akan digunakan dalam uji antibakteri.

\section{Pembuatan Kontrol Positif dan Kontrol Negatif}

Kontrol positif untuk pengujian aktivitas antibakteri ini menggunakan gel spot "Acnes ${ }^{\circledR}$ " dan untuk kontrol negatif menggunakan basis masker peel-off.
Uji Aktivitas Antibakteri

1. Bahan uji sediaan masker peel-off ekstrak daun Alpukat dengan konsentrasi 0,1\%; 0,15\%; 0,2\%; $0,25 \%$ dan $0,3 \%$ dimasukkan pada sumursumur yang berbeda sebanyak 0,1 gram menggunakan sudip.

2. Basis masker gel digunakan sebagai kontrol negatif dimasukkan pada sumur-sumur sebanyak 0,1 gram menggunakan sudip.

3. Gel spot “Acnes ${ }^{\circledR}$ " digunakan sebagai kontrol positif dimasukkan pada sumur- sumur sebanyak 0,1 gram menggunakan sudip.

4. Kemudian cawan petri diinkubasi dalam inkubator pada suhu $37^{\circ} \mathrm{C}$ selama 24 jam.

\section{Pengamatan dan Pengukuran}

Pengamatan dilakukan setelah 1×24 jam masa inkubasi. Daerah bening merupakan petunjuk kepekaan bakteri terhadap antibiotik atau bahan antibakteri lainnya yang digunakan sebagai bahan uji yang dinyatakan dengan lebar diameter zona hambat. Diameter zona hambat diukur dalam satuan millimeter ( $\mathrm{mm})$ menggunakan jangka sorong dengan cara diameter keseluruhan dikurangi diameter sumuran $7 \mathrm{~mm}$. Selanjutnya diameter zona hambat tersebut dikategorikan kekuuatan daya antibakteri sesuai dengan krteria kekuatan daya antibakteri menurut Davis and Stout

\section{Hasil dan Pembahasan}

Dalam penelitian ini pembuatan masker peel-off ekstrak etanol daun Alpukat mengunakan basis PVA (polivinil alkohol) sebagai plasticizer, Hidroksipropil Metilselulosa (HPMC) sebagai peningkat viskositas, gliserin sebagai humektan, TEA sebagai zat pengemulsi dan aquadest digunakan sebagai pelarut.

Sampel basah daun Alpukat diperoleh sebanyak 3,4 kg dan diperoleh sampel kering sebanyak 2,6 kg. Pengeringan ini bertujuan untuk untuk menurunkan kadar air dalam daun Alpukat. Pengurangan kadar air dalam sampel bertujuan agar proses enzimatik dimana kandungan kimia yang terkandung dalam bahan diubah menjadi produk lain atau dirusak oleh enzim. Tanda sampel yang sudah kering yaitu apabila ketika diremas menggunakan tangan sampel mudah dipatahkan. Mudah dipatahkannnya sampel ini menunjukkan bahwa sampel tersebut kandungan airnya kurang dari 10\% (Sitepu, 2010), pengeringan juga mencegah adanya bertumbuhnya kapang dan jamur sehingga sampel dapat disimpan dalam waktu yang lama. Kemudian menghasilkan serbuk simplisia sebanyak 400 gr. Pembuatan simplisia ini bertujuan untuk memperbesar luas permukaan sampel yang akan berinteraksi dengan pelarut sehinga senyawasenyawa yang ada dalam sampel dapat larut lebih banyak.

Ekstraksi yang dilakukakan pada penelitian ini menggunakan metode maserasi. Proses maserasi juga mempunyai keuntungan lain dari metode 
ekstraksi lainnya yaitu cara pengerjaannya yang sederhana dan peralatan yang mudah didapat, sederhana dan tidak memerlukan alat yang khusus dan juga metode maserasi dipilih karena merupakan metode yang paling umum digunakan dalam pembuatan ekstrak bahan alam. Pemilihan pelarut dalam ekstraksi merupakan salah satu faktor penting karena dapat mempengaruhi suatu keberhasilan ekstraksi. Pelarut yang digunakan dalam ekstraksi ini yaitu etanol 96\% menurut (Tiwari $d k k, 2011)$, etanol merupakan pelarut yang bersifat universal dan selektif dalam melarutkan senyawasenyawa kimia yang dinginkan dan lebih efisien dalam degradasi dinding sel yang beersifat non polar sehingga polifenol akan tersari lebih banyak. Ekstrak kental yang diperoleh selama proses maserasi yaitu sebanyak $43 \mathrm{~g}$.

Hasil penelitian yang didapat dari uji antibakteri terhadap sediaan masker gel peel off dengan konsentrasi $0,1 \%$; $0,15 \%$; $0,2 \%$; $0,25 \%$ dan $0.3 \%$ menujukkan bahwa lebih besar menghambat bakteri pada konsentrasi $0.3 \%$ dengan rerata daya hambat sebesar $3 \mathrm{~mm}$. Hasil rerata daya hambat dapat dilihat dalam garfik berikut:

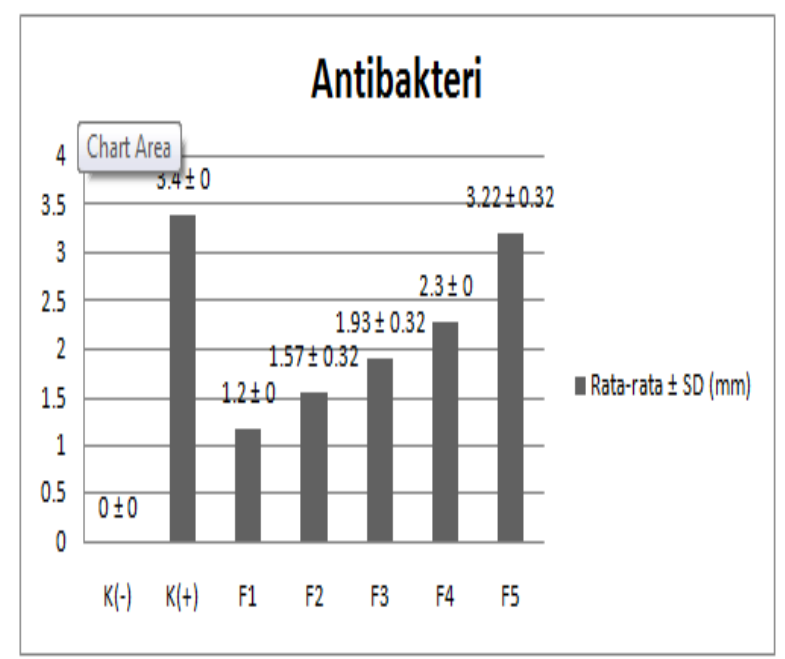

Keterangan :

K (-) : Kontrol Negatif (Basis Sediaan); K (+) : Kontrol Positif (Gel Spot "Acnes); F1 : Formula 1 Sediaan Masker Gel peel off konsentrasi 0,1\%; F2 : Formula 2 Sediaan Masker Gel peel off konsentrasi 0,15\%; F3 : Formula 3 Sediaan Masker Gel peel off konsentrasi 0,2\%; F4 : Formula 4 Sediaan Masker Gel peel off konsentrasi $0,25 \%$; F5 : Formula 5 Sediaan Masker Gel peel off konsentrasi $0,3 \%$.

Hasil dari uji antibakteri terhadap bakteri Staphylococcuss epidermidis menunjukkan bahwa rerata daya hambat tertinggi dari ekstrak etanol daun Alpukat (Persea americana Mill.) yang diformuasikan dalam sediaan masker peel off yaitu pada konsentrasi $0.3 \%$ dengan rerata diameter daya hambat sebesar $3 \mathrm{~mm}$ dan tergolong daya hambat yang lemah.

\section{Kesimpulan}

Konsentrasi terbesar ekstrak etanol daun Alpukat (Persea americana Mill.) yang diformulasikan sebagai sediaan Masker Peel Off berdasarkan uji antibakteri terhadap bakteri Staphylococcus epidermidis didapatkan hasil pada konsentrasi 0,3\% dengan rerata diameter zona hambat sebesar $3 \mathrm{~mm}$.

\section{Daftar Pustaka}

Christianto, C.W., Nurwati, dan D. Istiati. 2012. Efek Antibakteri Ekstrak Biji Alpukat (Persea americana Mill) terhadap pertumbuhan Streptococcus mutans. Oral Biol Dent Journal. 4(2) : 40-44.

Cushnie, T. P and Lamb, A. J., 2005. Antimicrobial Avtivity of Flavonoids. International Journal of Antimicrobial Agents. Elsevier, UK.

Pardiansyah, R. 2015. Association Between Personal Protective Equipment with the Irritant Contact Dermatitist in Scavengers. Faculty of Medicine Lampung University, Lampung.

Djajadisastra, J., Mun'im A., dan Dessy N.P. 2009. Formulasi Gel Topikal dari Ekstrak Nerii Folium dalam Sediaan Anti Jerawat. JFI. 4(4): 210-216.

Edy, H.J., Marchaban S., Wahyuno E., dan Nugroho A.E. 2016. Formulasi dan Uji Sterilitas Hidrogel Herbal Ekstrak Etanol Daun Tagetes erecta L. Pharmacon Jurnal Ilmiah Farmasi. 5(2).

Edy, H.J., Marchaban S., Wahyuno E., dan Nugroho A.E. 2017. Formulation and Evaluation of Hydrogel Containing Tagetes erecta L. Leaves Etanolic Extract

Yeom, G., D.M. Yun, Y.W. Kang, J.S. Kwan, I.O. Kang, S.Y. Kim,. 2011. Clinical efficacy of facial masks containing yoghurt and Opuntia humifusa Raf. (F-YOP). J. cosmet Sci. 62 (5): 505-514.

Yunikasari, D., J. Waluyo, S. Murdiyah. 2016. Uji Daya Hambat Ekstrak Etanol Daun Alpukat (Persea americana Mill.) terhadap Pertumbuhan Bakteri Staphylococcus epidermidis. Seminar Nasional Pendidikan Biologi II. FKIP. Program Studi Pendidikan Biologi. Universitas Jember. Jember. 